\title{
Opaque intraocular lens for correction of intractable diplopia and torticollis
}

\author{
Valentin Huerva, ${ }^{1}$ Cristina Pont, ${ }^{2}$ Diego Castanera ${ }^{1}$
}

${ }^{1}$ Universitary Hospital Arnau de Vilanova, Ophthalmology, Lleida, Spain

${ }^{2}$ Universitary Hospital Arnau de vilanova, Ophthalmology, Lleida, Lleida, Spain

\section{Correspondence to DrValentin Huerva, vhuerva@gmail.com}

Accepted 14 July 2017

\section{(1) \\ CrossMark}

To cite: Huerva $\mathrm{V}$, Pont $\mathrm{C}$, Castanera D. BMJ Case Rep Published Online First: [please include Day Month Year]. doi:10.1136/bcr-2017221242

\section{DESCRIPTION}

A 72-year-old woman was referred to our hospital for treatment of persistent diplopia and bilateral large angle of esotropia ( $>50$ prismatic dioptres): She had a 12-year previous history of double vision attributed to double paralysis of the VI nerve after a traffic accident. In order to avoid double vision, she permanently misplaced her head in torticollis by turning it all the way to the left. The left eye was the fixator and the view of the right eye was occluded by the nose (figure 1). Due to this, the patient suffered cervical contractures and experienced poor quality of life.

On examination, best-corrected visual acuities were 20/70 in the right eye and 20/30 in the left eye. Orthoptic assessment revealed a complete paralysis of both VI cranial nerves with total absence of abduction. The eyes did not reach the midline and remained in complete esotropia. The III and IV nerves were not affected. A nuclear cataract was present in both eyes and fundus examination was normal.

In a first intervention, the patient underwent strabismus surgery in both eyes $(6 \mathrm{~mm}$ recession of both medial rectus muscles and $10 \mathrm{~mm}$ shortening of both lateral recti). The esotropia improved to 35 prismatic dioptres, with significant improvement in the patient's torticollis, while diplopia persisted (figure 2). Further vertical muscle transfer was declined by the patient as it might have required several corrective surgeries, and would not have completely relieved her diplopia when attempting lateral or vertical gaze (despite becoming aligned in the primary position). She wanted to avoid diplopia and improve her quality of life.

Therefore, occlusive methods were considered and discussed with the patient. Glasses with a single fogged lens could remove the diplopia, but were not

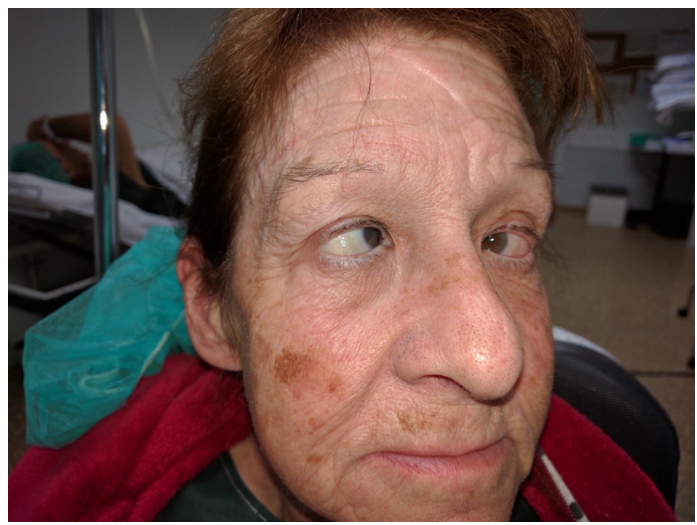

Figure 1 Torticollis and large bilateral esotropia.

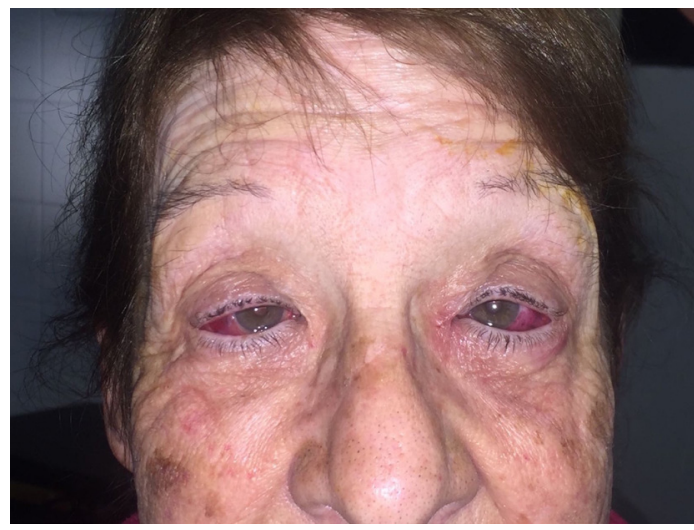

Figure 2 First postoperative day. Improvement of the esotropia.

considered aesthetic. She would also be forced to wear glasses permanently. An eye patch was also not considered acceptable. Botulinum toxin to induce ptosis would also require repeated injections and would also not be aesthetic. An opaque contact lens was also discarded in this case due to the difficulty of placing and removing the lens daily and given the patient's age and cost involved in maintaining the lens. Permanent corneal tattooing could be yet another option, but might give a disfigured appearance and carries risk of iatrogenic corneal irritation and injury. ${ }^{1}$ It also is not easily reversible.

Therefore, an opaque intraocular lens was considered. First of all, it is a reversible method. The lens can be removed and a new conventional intraocular lens (IOL) implanted in case of any traumatic or retinal pathology such as age-related macular degeneration, venous occlusion, and so on, in the contralateral eye. Moreover, it does not require any ongoing cost or repeated procedures to maintain the desired effect. After a thorough

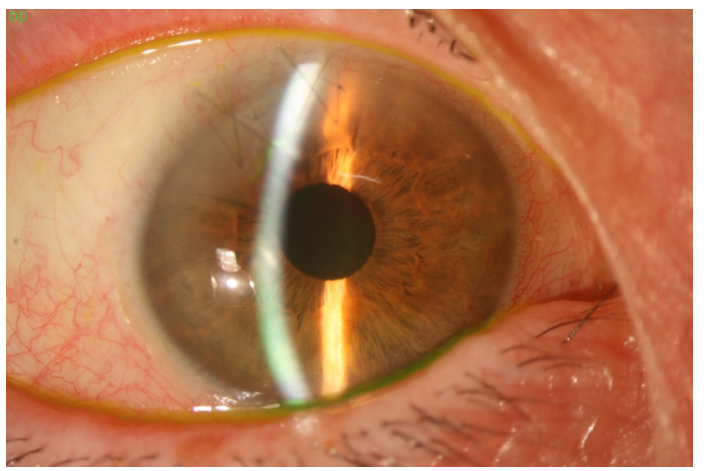

Figure 3 Opaque intraocular IOL in the capsular bag of the right eye. 


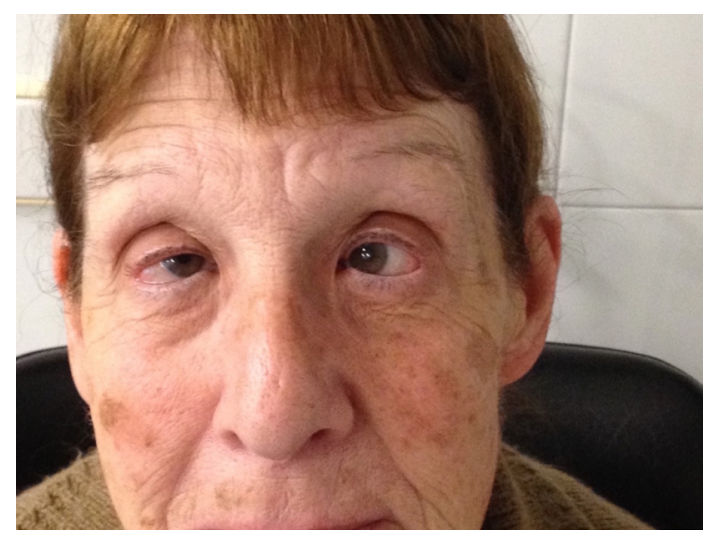

Figure 4 Remainder esotropia. Absence of diplopia and torticollis.

\section{Learning points}

- Chronic high esotropia secondary to complete bilateral palsy of the $\mathrm{VI}$ nerve may improve with the weakening of the contracted medial rectus muscles without a vertical muscle transposition.

- An implantation of an opaque lens after cataract extraction in the not fixator eye may remove the diplopia and improve the torticollis. discussion of the risks, benefits and alternatives, she wished to proceed with the opaque intraocular lens insertion. Three months after the strabismus surgery she underwent an uncomplicated phacoemulsification of the right cataract and insertion of an opaque IOL $6.0 \mathrm{~mm}$ diameter (Morcher 85F, Germany) into the capsular bag (figure 3). The strabismus persisted, however the remaining esotropia was useful for close-up and reading jobs. She is happy and her quality of life has improved. Her torticollis also improved (figure 4).

An opaque IOL insertion may be an acceptable option in the management of intractable and persistent diplopia, strabismus, nerve palsies, loss of central fusion, leucocoria and previous retinal detachment surgery. ${ }^{2-4}$

Patient consent Obtained.

Provenance and peer review Not commissioned; externally peer reviewed.

(c) BMJ Publishing Group Ltd (unless otherwise stated in the text of the article) 2017. All rights reserved. No commercial use is permitted unless otherwise expressly granted.

\section{REFERENCES}

1 Dawson E, Maino A, Lee J. A unique use for a corneal tattoo. Strabismus 2009;17:98-100.

2 Hadid $\mathrm{OH}$, Wride NK, Griffiths PG, et al. Opaque intraocular Lens for intractable diplopia: experience and patients' expectations and satisfaction. $\mathrm{Br} J$ Ophthalmol 2008;92:912-5.

3 Kwok T, Watts P. Opaque intraocular Lens for intractable diplopia-UK survey. Strabismus 2009;17:167-70.

4 Lee RM, Dubois VD, Mavrikakis I, et al. Opaque intraocular Lens implantation: a case series and lessons learnt. Clin Ophthalmol 2012;6:545-9.

Copyright 2017 BMJ Publishing Group. All rights reserved. For permission to reuse any of this content visit http://group.bmj.com/group/rights-licensing/permissions.

BMJ Case Report Fellows may re-use this article for personal use and teaching without any further permission.

Become a Fellow of BMJ Case Reports today and you can:

- Submit as many cases as you like

- Enjoy fast sympathetic peer review and rapid publication of accepted articles

- Access all the published articles

- Re-use any of the published material for personal use and teaching without further permission

For information on Institutional Fellowships contact consortiasales@bmjgroup.com

Visit casereports.bmj.com for more articles like this and to become a Fellow 